\title{
Weight-length relationships for commercial fish species caught in Lake Hlan in Benin (West Africa)
}

\author{
Elie MONTCHOWUI ${ }^{1 *}$, Marie-José KOGBETO ${ }^{2}$ and Philippe LALEYE ${ }^{1}$ \\ ${ }^{1}$ Laboratory of Hydrobiology and Aquaculture, University of Abomey-Calavi, 01BP526 Cotonou, Benin. \\ ${ }^{2}$ CERPA Mono-Couffo, Comè Sector, BP 31 Lokossa, Benin. \\ *Corresponding author, E-mail: e.montchowui@yahoo.fr
}

\begin{abstract}
The present study describes the weight-length relationships (WLR) for 11 important commercial fish species caught in Lake Hlan in Benin. These species were collected by means of traditional fishing gear (traps, gill nets, bar mesh and hooks) from September 2004 to August 2005. A total of 1292 specimens were used to estimate the parameters of the relationship. The $\mathrm{b}$ values ranged between 2.706 in Heterotis niloticus and 4.038 in Chrysichthys nigrodigitatus, with a mean of $3.218 \pm 0.121$. The correlation coefficients of the WLR regressions ranged from 0.94 to 1.00 and were all statistically significant. All relationships were highly significant.
\end{abstract}

(C) 2009 International Formulae Group. All rights reserved.

Keywords: Condition factors, Lake Hlan, Benin.

\section{INTRODUCTION}

Among the several applications of weight-length relationships (WLR) in fish biology, knowledge of these relationships is useful for the prediction of weight from length values as an indication of fish condition or for fish stock assessment (Petrakis and Stergiou, 1995). This relationship has also been used to compare species growth between different regions (Froese and Pauly, 1998; Koutrakis and Tsikliras, 2003).

In Benin, the first data on lengthweight relationships was reported for some fish species from the Ouémé River (Lalèyè, 2006), but similar data for fish species from most of the other water bodies is still missing.

Lake Hlan is an important water body of water whose fishery resources play a significant role in the economy and food habits of the local people. Lake Hlan is subjected to a comparatively low level of exploitation owing to local enforcement of traditional fishing regulations. Little is known about the ecology and biology of most of the captured species. It is therefore imperative to understand the basic features of the demography of these fishes. As a first approach to the study of the biology of fish species in this lake, this study estimates the weight-length relationship of 11 commercial fish species captured by artisanal fishing in Lake Hlan, also one of the most important fishing grounds in southern Benin.

\section{MATERIALS AND METHODS}

Study area

The study was carried out on Lake Hlan in Benin. Lake Hlan $\left(6^{\circ} 56^{\prime} 35,05^{\prime \prime} \mathrm{N}\right.$, $2^{\circ} 19^{\prime} 57,32^{\prime \prime} \mathrm{E}$ ) (Figure 1) is located near Kpomey village (Sehoue County) about 80 $\mathrm{km}$ from the Atlantic coast.

The climate of the region is characterized by a transition between the subequatorial climate from the coast and the 
wet tropical climate of the Sudano-Guinean type from northern Benin. According to Adam and Boko (1993), this climate is characterized by a long wet season (mid-March to mid-July) and a short wet season (mid-September to October), a long dry season (November to mid-March) and a shorter one (August to midSeptember).

The lake has one annual period of low waters (November-May) and a period of high waters (July-September).
Several physical and chemical parameters were measured during the study period. The rate of dissolved oxygen and water temperature were measured with a digital oxythermometer (Voltcraft). Depth and water transparency were measured using a Secchi disk. $\mathrm{pH}$ was measured using a portable $\mathrm{pH}$ meter (pHScan 10). Conductivity and total dissolved solids (TDS) were measured with a conductivity meter (pIONeer

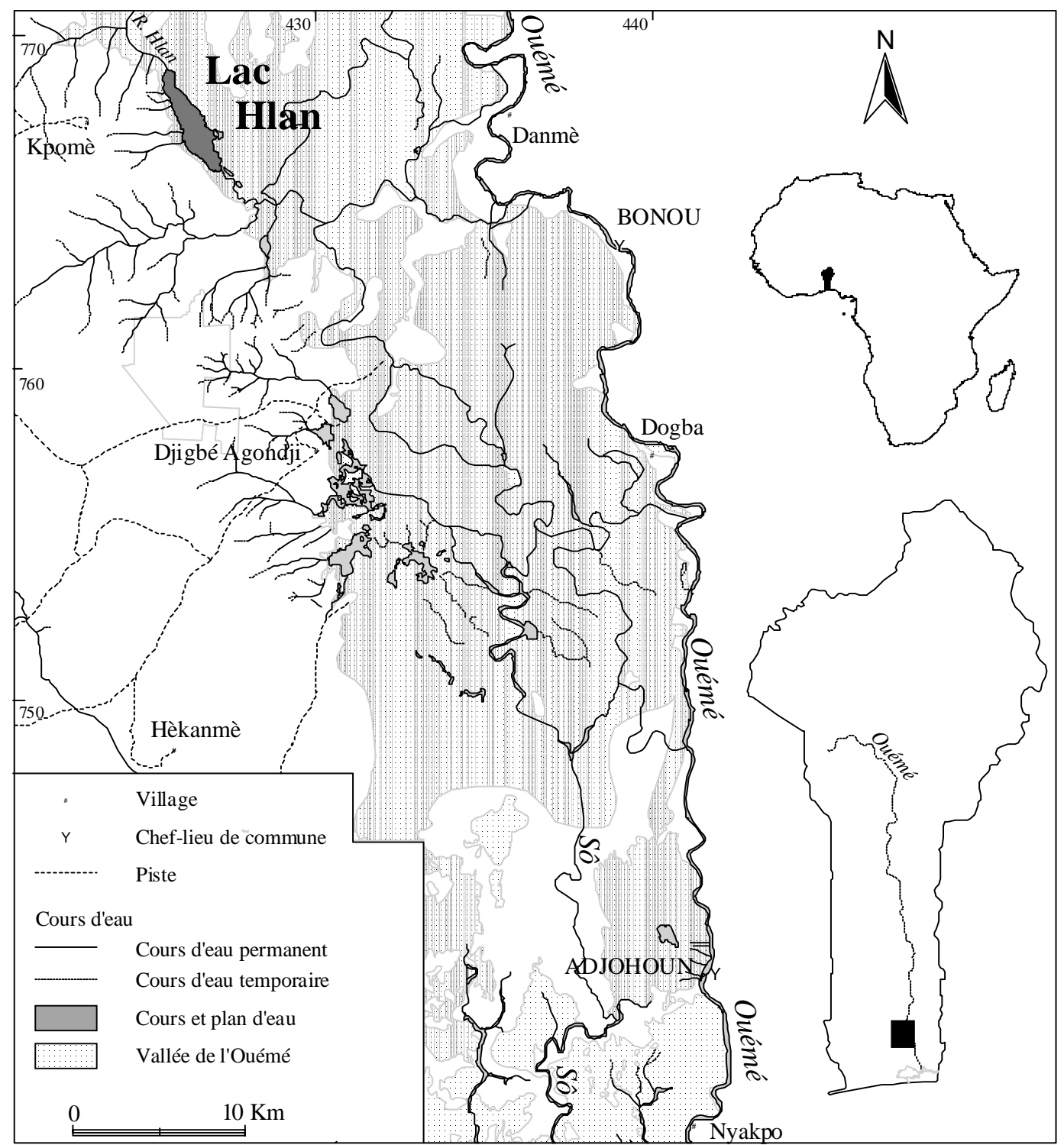

Figure 1: Map of Lake Hlan. 
30, Radiometer Analytical). Nitrite and total iron were measured using spectrophotometer (Hach DR/2010; HACH Instruments). Dissolved oxygen (measured between 0800 and $1000 \mathrm{~h}$ ) ranged from $2.43 \mathrm{mg} / \mathrm{l}$ to 5.32 $\mathrm{mg} / \mathrm{l}$. Water transparency averaged $80.0 \pm 20.0$ $\mathrm{cm}$, mean water temperature was recorded at $28.6 \pm 1.2{ }^{\circ} \mathrm{C}$ and ranged from 26.5 to $31.6{ }^{\circ} \mathrm{C}$, mean $\mathrm{pH} 6.9 \pm 0.5$, average conductivity $79.0 \pm 3.0 \mu \mathrm{S} / \mathrm{cm}$ and mean TDS $37.4 \pm 1.4$ $\mathrm{mg} / \mathrm{l}$. Nitrite and total iron concentration were low and averaged $0.002 \pm 0.001$ and $0.68 \pm 0.25$ $\mathrm{mg} / 1$, respectively.

Floating grasses, such as Cyperus difformis (Cyperaceae), cover large areas of the lake and hinder fishing activities. Winddriven movement of grass mats sometimes damages fishing gear. These grasses also provide habitat for many aquatic organisms, including small fishes. Water hyacinth is present in Lake Hlan, but at low biomass compared with most areas of the river channel. Other common floating macrophytes in Lake Hlan were Pistia stratiotes, Azolla africana, Nymphaea lotus and Nymphaea maculatus (Nymphaeacea), Echhornia crassipes and Echinochloa pyramides (Poacee). Submerged plants included Ceratophyllum demersum (Ceratophyllaceae) and Utricularia inflexa (Lantibulariaceae).

\section{Fish samples and data analysis}

Fishes were surveyed every month from September 2004 to August 2005. Fishes were collected by means of traditional fishing gear (traps, gill nets, bar mesh and hooks). Taxonomic identification was performed according to Lévêque et al. (1990; 1992). Specimens were weighed (body weight [BW], to the nearest $0.1 \mathrm{~g}$ ), measured (total length (TL) and standard length (SL), to the nearest centimetre). The sex of the fish was determined by macroscopic examination of the gonads after dissection.

The length-weight relationship was estimated for each species by linear regression analysis fitted by the least-squares method over log-transformed data $(\mathrm{LnW}=\mathrm{Lna}+\mathrm{b}$ LnTL), where $b$ is the slope and $\log a$ is the intercept of the straight line relationship. The statistical significance of $r^{2}$ was estimated and the $b$ value tested using the t-test to verify if it was significantly different from the isometric $(b=3)$. All the analyses were performed using
STATVIEW software (Version 1992-98, SAS Institute Inc).

\section{RESULTS}

A total of 1292 fishes were used for the analysis; the minimum sample size was 12 fishes (Chrysichthys nigrodigitatus). The sample size, length range, type of growth, parameters $a$ and $b$, and coefficient of determination $\left(\mathrm{r}^{2}\right)$ are presented in table 1 for the 11 species. The correlation coefficients of the WLR regressions ranged from 0.94 to 1.00 and were all statistically significant $(\mathrm{P}<0.0001)$. All of the weight-length relationships were highly significant $(\mathrm{p}<0.001)$.

\section{DISCUSSION}

In this study, the $\mathrm{b}$ value ranged from 2.706 in Heterotis niloticus to 4.038 in Chrysichthys nigrodigitatus. These results are in accordance with the range of values for this parameter usually encountered in fish, between 2 and 4 according to Bagenal and Tesch (1978). Recently, Froese (2006) confirmed Carlander's suggestion (1969) that the $b$ exponent should normally fall between 2.5 and 3.5. Carlander (1977) demonstrated that $b$ values less than 2.5 or greater than 3.5 are mostly caused by samples with narrow size ranges. We consider our results to be an adequate estimation of the weight-length relationship, since the $\mathrm{b}$ parameter falls within the expected range of 2.5-3.5.

The fishes in Lake Hlan undergo two types of growth: either isometric growth for Chrysichthys auratus, Tilapia zillii and Clarias gariepinus or allometric growth for Heterotis niloticus, Gymnarchus niloticus, Hepsetus odoe, Chrysichthys nigrodigitatus, Parachanna obscura, Hemichromis fasciatus, Tilapia mariae and Sarotherodon galilaeus (Table 1). These results indicate that the growth in length is equal to the growth in weight for species such as Chrysichthys auratus, Tilapia zillii and Clarias gariepinus. In contrast, in species such as Gymnarchus niloticus, Hepsetus odoe, Chrysichthys nigrodigitatus, Parachanna obscura, Hemichromis fasciatus and Tilapia mariae, the growth in weight is greater than the growth in length. In Heterotis niloticus and Sarotherodon galilaeus, the growth in length is more substantial than the growth in weight. 
The majority of these commercial species caught in Lake Hlan have $b$ values higher than the hypothetical isometry value (3), showing that the lake area offers good conditions to these populations. Lake Hlan lies in a vast and densely vegetated flood plain which provides abundant food resources that support rapid growth in these fishes. During the wet and flood seasons, the fishes accessed seeds from submerged and emerged terrestrial vegetation, explaining why the majority of fishes were healthy.

There were marked differences in $b$ values between the species in Lake Hlan and populations elsewhere. For the species Heterotis niloticus, Parachanna obscura, Tilapia mariae and Sarotherodon galilaeus, Lalèyè (2006) reported the isometric growth and the allometric growth for Chrysichthys auratus in the Ouémé River (Benin). Britton and Harper (2006) reported the positive allometry growth for $T$. zillii and $C$. gariepinus in the rift valley lakes of Kenya. The causal factors of these differences were likely to be varied and include the number of specimens examined, their size range and reproductive stage, and the waters experiencing different climatic and environmental variables (Bagenal and Tesch, 1978; Petrakis and Stergiou, 1995; Moutopoulos and Stergiou, 2002; Oscoz et al., 2005; Froese, 2006).

The study presented herein is an additional contribution to the available WLR in the Benin area. This research provides the first data on WLR for fish species in Lake Hlan.

\section{ACKNOWLEDGEMENTS}

The authors are grateful to the INRAB (Institut National des Recherches Agricoles du Bénin) and the ABE (Agence Béninoise pour l'environnement) for supporting this work financially. We also thank the fishermen who helped collect the data on the area. We also thank the anonymous reviewers for their comments on previous drafts of the manuscript.

Table 1: WLR parameters for 11 important commercial fish species caught in Lake Hlan.

\begin{tabular}{|c|c|c|c|c|c|c|c|}
\hline \multirow{2}{*}{ Family/Species } & \multicolumn{3}{|c|}{ Total length $(\mathrm{cm})$} & \multicolumn{3}{|c|}{ WLR parameters } & \multirow{2}{*}{ Growth } \\
\hline & $\mathbf{N}$ & Min & $\operatorname{Max}$ & $\mathbf{a}$ & $\mathbf{b}$ & $\mathbf{r}^{2}$ & \\
\hline $\begin{array}{l}\text { Osteoglossidae: } \\
\text { Heterotis niloticus }\end{array}$ & 123 & 26.5 & 80.0 & -3.588 & 2.706 & 0.94 & A- \\
\hline $\begin{array}{l}\text { Gymnarchidae: } \\
\text { Gymnarchus niloticus }\end{array}$ & 30 & 24.7 & 96.0 & -7.801 & 3.496 & 0.95 & $\mathrm{~A}+$ \\
\hline $\begin{array}{l}\text { Hepsetidae: } \\
\text { Hepsetus odoe }\end{array}$ & 19 & 10.0 & 37.0 & -6.484 & 3.502 & 0.98 & $\mathrm{~A}+$ \\
\hline $\begin{array}{l}\text { Claroteidae: } \\
\text { Chrysichthys nigrodigitatus } \\
\text { Chrysichthys auratus }\end{array}$ & $\begin{array}{l}20 \\
80\end{array}$ & $\begin{array}{l}16.2 \\
15.3\end{array}$ & $\begin{array}{l}30.5 \\
34.5\end{array}$ & $\begin{array}{l}-7.518 \\
-4.400\end{array}$ & $\begin{array}{l}4.038 \\
2.914\end{array}$ & $\begin{array}{l}0.96 \\
0.89\end{array}$ & $\begin{array}{c}\mathrm{A}+ \\
\mathrm{I}\end{array}$ \\
\hline $\begin{array}{l}\text { Clariidae: } \\
\text { Clarias gariepinus }\end{array}$ & 37 & 15.0 & 60.0 & -5.074 & 3.077 & 0.98 & I \\
\hline $\begin{array}{l}\text { Channidae: } \\
\text { Parachanna } \\
\text { obscura } \\
\end{array}$ & 60 & 7.5 & 39.0 & -6.697 & 3.622 & 0.95 & $\mathrm{~A}+$ \\
\hline $\begin{array}{l}\text { Cichlidae: } \\
\text { Hemichromis fasciatus } \\
\text { Tilapia mariae } \\
\text { Tilapia zillii } \\
\text { Sarotherodon galilaeus }\end{array}$ & $\begin{array}{c}97 \\
164 \\
412 \\
250\end{array}$ & $\begin{array}{c}2.5 \\
2.3 \\
10.7 \\
9.1\end{array}$ & $\begin{array}{l}15.8 \\
24.2 \\
31.2 \\
31.8\end{array}$ & $\begin{array}{l}-4.532 \\
-4.102 \\
-3.778 \\
-3.482\end{array}$ & $\begin{array}{l}3.158 \\
3.093 \\
2.940 \\
2.850\end{array}$ & $\begin{array}{l}0.99 \\
0.98 \\
0.88 \\
0.88\end{array}$ & $\begin{array}{c}\mathrm{A}+ \\
\mathrm{A}+ \\
\mathrm{I} \\
\mathrm{A}-\end{array}$ \\
\hline
\end{tabular}

(N: sample size; Min: minimum; Max: maximum; $a$ and $b=$ parameters of equation $W=a L^{b} ; r^{2}$ : coefficient of determination; I: isometric; A: allometric). 


\section{REFERENCES}

Adam KS, Boko M. 1993. Le Bénin. Edicef: Paris, France.

Bagenal TB, Tesch FW. 1978. Age and growth (Chapter 5). In Methods for Assessment of Fish Production in Fresh Waters, Bagenal T (ed). IBP Handbook No. 3, ( $3^{\text {rd }}$ edn), Blackwell Scientific Publications: Oxford, UK; 101-136.

Britton JR, Harper DM. 2006. Length-weight relationships of fish species in the freshwater rift valley lakes of Kenya. $J$. Appl. Ichthyol., 22: 334-336.

Carlander KD. 1969. Handbook of Freshwater Fishery Biology. (Vol. 1). The Iowa State University Press: Ames, IA.

Carlander KD. 1977. Handbook of Freshwater Fishery Biology. (Vol. 2). The Iowa State University Press: Ames, IA.

Froese R. 2006. Cube law, condition factor and weight-length relationships: history, meta-analysis and recommendations. $J$. Appl. Ichthyol., 22: 241-253.

Froese R, Pauly D. 1998. Fishbase 1998: concepts, design and data sources. ICLARM: Manila.

Koutrakis ET, Tsikliras AC. 2003. Lengthweight relationships of fishes from three northern Aegean estuarine systems (Greece). J. Appl. Ichthyol., 19: 258-260.

Lalèyè P. 2006. Length-weight and lengthlength relationships of fishes from Ouémé river in Bénin (West Africa). J. Appl. Ichthyol., 22: 330-333.

Levêque C, Paugy D, Teugels GG. 1990. Faune des Poissons d'Eaux Douces et Saumâtres de l'Afrique de l'Ouest. (Tome 1). Collection Faune Tropicale, $\mathrm{n}^{\circ} \mathrm{XXVIII.}$ ORSTOM/MRAC: Paris.

Levêque C, Paugy D, Teugels GG. 1992. Faune des Poissons d'Eaux Douces et Saumâtres de l'Afrique de l'Ouest. (Tome 2). Collection Faune Tropicale, $\mathrm{n}^{\circ}$ XXVIII. ORSTOM/MRAC: Paris.

Moutopoulos DK, Stergiou KI. 2002. Lengthweight and length-length relationships of fish species from the Aegean Sea (Greece). J. Appl. Ichthyol., 18: 200-203.

Oscoz J, Escala MC, Campos F. 2005. Weight-length relationships of some fish species of the Iberian Peninsula. J. Appl. Ichthyol., 21: 73-74.

Petrakis G, Stergiou KI. 1995. Weight-length relationships for 33 fish species in Greek waters. Fish. Res., 21: 465-469. 